\title{
Pengaruh model discovery learning berbantuan lembar kegiatan siswa (LKS) terhadap kemampuan berpikir analitis siswa kelas XI SMA Negeri 1 Gondanglegi
}

\author{
Filia Rani Artanti, Dwiyono Hari Utomo*, Alfi Sahrina \\ Universitas Negeri Malang, Jl. Semarang No. 5 Malang, Jawa Timur, Indonesia \\ *Penulis korespondensi, Surel: dwiyono.hari.fis@um.ac.id
}

Paper received: 02-03-2021; revised: 15-03-2021; accepted: 30-03-2021

\begin{abstract}
Abstrak
Model Discovery Learning dipilih dalam penelitian ini karena beberapa alasan. Alasan tersebut diantaranya: (1) Discovery Learning sesuai dengan kurikulum 2013, (2) Discovery Learning memiliki kegiatan pengalaman langsung dan memotivasi siswa untuk memecahkan masalah, serta (3) Discovery Learning melatih kemampuan berpikir analitis. Penelitian ini bertujuan untuk mengetahui pengaruh model Discovery Learning Berbantuan LKS terhadap kemampuan berpikir analitis siswa kelas XI SMA Negeri 1 Gondanglegi. Rancangan penelitian ini menggunakan eksperimen semu (quasi eksperiment) dengan desain posttest only control grup design. Penelitian ini menggunakan dua kelas sebagai subjek penelitian yaitu kelas XI IPS 3 sebagai kelas eksperimen dan kelas XI IPS 2 sebagai kelas kontrol. Kelas eksperimen diberikan perlakuan dengan model Discovery Learning berbantuan LKS dan kelas kontrol diberikan perlakukan dengan pembelajaran konvensional. Pemilihan subjek penelitian tersebut menggunakan purposive sampling yang memiliki nilai rata-rata ulangan harian yang hampir sama. Instrumen yang digunakan yaitu soal essay kemampuan berpikir analitis. Hasil penelitian menunjukkan bahwa nilai rata-rata kemampuan berpikir analitis siswa pada kelas eksperimen yang diberikan perlakuan dengan model Discovery Learning memiliki nilai rata-rata yang lebih tinggi $(82,00)$ dibandingkan dengan kelas kontrol yang diberikan permbelajaran konvensional $(75,59)$. Hasil analisis uji-T mendapatkan nilai signifikansi 0,003 atau <0,05. Maka dapat disimpulkan bahwa (H0) ditolak dan (H1) diterima, sehingga model pembelajaran Discovery Learning berbantuan lembar kegiatan siswa (LKS) berpengaruh terhadap kemampuan berpikir analitis siswa kelas XI SMA Negeri 1 Gondanglegi.
\end{abstract}

Kata kunci: Model Discovery Learning; kemampuan berpikir analitis

\section{Pendahuluan}

Kemampuan berpikir analitis diperlukan bagi siswa untuk melatih menyelesaikan masalah yang dihadapi berdasarkan fakta-fakta yang ditemukan sebagai dasar pengambilan keputusan dalam proses pembelajaran. Hal tersebut sesuai dengan pendapat Anderson dalam Astriani dkk (2017) bahwa kemampuan berpikir analitis termasuk dalam kemampuan berpikir tingkat tinggi yang penting untuk melatih siswa dalam memahami informasi secara mendalam, terperinci dan mampu menghubungkan antar komponen. Jadi apabila kecakapan analisis dapat berkembang pada siswa maka siswa tersebut akan mampu mengatasi permasalahan yang mereka hadapi pada fakta-fakta yang ditemukan dan mengambil keputusan dari permasalahan tersebut serta mampu mengaplikasikannya pada situasi baru secara kreatif.

Dalam proses pembelajaran geografi melatih kemampuan berpikir analitis dipandang penting. Kemampuan berpikir analitis dapat mendorong siswa untuk menggunakan logikanya dalam menghadapi masalah dan menemukan solusi dalam permasalahan yang terdapat dilingkungannya. Studi geografi tidak hanya mempelajari yang berkaitan dengan alam semesta saja, tetapi juga permasalahan yang ada dilingkungan siswa pada saat ini. Kompetensi dasar 
dari mata pelajaran geografi sudah terfokus dalam tahap menganalisis, sehingga kemampuan berpikir analitis harus dikembangkan. Pembelajaran geografi yang awalnya dipandang sebagai ilmu hafal tetapi dapat diubah dengan kemampuan menganalisis siswa dari permasalahan yang mereka hadapi di lingkungan mereka. Maka dari itu, pembelajaran geografi tidak hanya bergelut dengan konsep-konsep atau pengetahuan yang ada saja, tetapi terdapat proses menganalisis permasalahan yang ada dilingkungan yang dapat dilakukan dengan beberapa kegiatan lapangan.

Salah satu model pembelajaran yang dapat digunakan untuk meningkatkan kemampuan berpikir analitis adalah model discovery learning. Enam sintaks yang ada pada model discovery learning sesuai dengan pendapat Syah (2004) yang meliputi stimulasi, identifikasi masalah, pengumpulan data, pengolahan data, verifikasi dan generalisasi. Dalam discovery learning siswa dilatih untuk mempelajari materi secara mandiri sehingga siswa mendapatkan pengalaman langsung yang dapat memudahkan siswa dalam mengingat pengetahuan yang didapatkan.

Model discovery learning memiliki beberapa kelebihan dalam mengembangkan kemampuan berpikir analitis siswa diantaranya: (1) siswa sebagai pusat dari proses pembelajaran, (2) siswa dihadapkan langsung dengan masalah yang ada di lapangan, (3) mengembangkan dan meningkatkan kemampuan dalam memecahkan masalah lewat pengalaman langsung. Maka dari itu dapat mengubah dari pembelajaran yang berpusat pada guru menjadi pembelajaran yang berpusat pada siswa, sehingga siswa mampu berperan aktif dan ikut andil dalam proses pembelajaran di kelas.

Motivasi belajar siswa dibutuhkan dalam model discovery learning yang menekankan pada keaktifan siswa. Untuk mendorong keaktifan siswa dibutuhkan media pembantu yang dapat mempermudah siswa mempelajari materi, sehingga dapat mengoptimalkan hasil belajar siswa. LKS salah satu media sederhana yang dapat membantu proses kegiatan belajar siswa. Menurut Depdiknas (2005) lembar kegiatan siswa adalah lembaran yang berisikan tugas, biasanya berupa petunjuk ataupun langkah yang digunakan untuk menyelesaikan tugas dalam kegiatan siswa yang dapat digunakan oleh guru untuk meningkatkan keterlibatan siswa dalam proses belajar mengajar.

Model pembelajaran discovery learning berbantuan LKS berpengaruh terhadap kemampuan analitis. Hal tersebut sesuai dengan hasil penelitian yang dilakukan oleh Imanda (2018) dan Angryawan (2016) menunjukkan adanya perbedaan antara kelas eksperimen dan kelas kontrol. Pada kelas eksperimen menunjukkan peningkatan dengan model discovery learning dibandingkan kelas kontrol yang menggunakan pembelajaran konvensional. Selain itu penelitian yang dilakukan oleh Riana (2016) juga menunjukan adanya pengaruh yang signifikan dari model discovery learning yang diterapkan pada kelas eksperimen.

\section{Metode}

Rancangan penelitian yang digunakan dalam penelitian ini yaitu pendekatan kuantitatif dengan jenis penelitian eksperimen semu (quasi experiment). Desain penelitian menggunakan posttest only control grup design. Pada desain ini kelompok eksperimen dan kelas kontrol diberikan tes setelah diberikan perlakuan yang berbeda. Kelompok eksperimen diberikan perlakuan dengan model pembelajaran discovery learning berbantuan LKS, sedangkan kelompok kontrol diberikan pembelajaran konvensional. 
Subjek penelitian ini adalah siswa kelas XI IPS SMA Negeri 1 Gondanglegi. Berdasarkan empat kelas IPS diambil dua kelas berdasarkan beberapa persamaan yaitu nilai rata-rata yang hampir sama dan kedua kelas tersebut juga. Penetuam kelas eksperimen menggunakan purposive random sampling dimana yang terpilih menjadi kelas eksperimen yaitu kelas XI IPS 3 yang akan mendapat perlakuan model pembelajaran discovery learning berbantuan LKS, dan kelas XI IPS 2 menjadi kelas kontrol dengan diberikan perlakuan menggunakan pembelajaran konvensional.

Instrumen yang digunakan dalam penelitian ini yaitu soal esai kemampuan berpikir analitis. Tujuan intrumen kemampuan berpikir analitis adalah untuk mengetahui kemampuan berpikir analitis siswa setelah diberikan perlakuan dengan model discovery learning berbantuan LKS. Isi instrumen kemampuan beripikir kritis yang digunakan untuk pengukuran kemampuan berpikir analitis siswa adalah soal posttest. Instrumen soal posttest diujicobakan pada kelas yang bukan digunakan dalam penelitian. Pengujian instrumen penelitian soal posttest meliputi uji validitas dan reliabilitas. Analitis data yang digunakan dalam penelitian antara lain uji prasyarat yang meliputi uji normalitas dan homogenitas serta uji hipotesis menggunakan Uji-t.

\section{Hasil dan Pembahasan}

Data dari hasil tes kemampuan berpikir analitis siswa kelas eksperimen dan kelas kontrol yang telah diberikan perlakuan berbeda dapat dijelaskan pada Tabel 1 dan Tabel 2.

Tabel 1. Distribusi Frekuensi Kemampuan Berpikir Analitis Siswa Kelas Eksperimen

\begin{tabular}{lllll}
\hline Klasifikasi & Nilai & Kualifikasi & Frekuensi & $\begin{array}{l}\text { Persentase } \\
(\%)\end{array}$ \\
\hline A & $86-100$ & Sangat Baik & 10 & 35,71 \\
B & $71-85$ & Baik & 14 & 50 \\
C & $56-70$ & Cukup & 4 & 14,29 \\
D & $41-55$ & Kurang & 0 & 0 \\
E & $\leq 40$ & Sangat Kurang & 0 & 0 \\
\hline Total & & & 28 & 100 \\
\hline
\end{tabular}

Data hasil dari distribusi frekuensi kemampuan berpikir analitis siswa kelas eksperimen (XI IPS 3) menunjukkan bahwa sebesar 85,71\% memiliki kemampuan berpikir analitis yang baik sampai sangat baik, dapat dilihat sebesar 35,71\% dengan jumlah sebanyak 10 siswa dikualifikasikan sangat baik kemampuan berpikir analitisnya, sedangkan sebesar $50 \%$ dengan jumlah 14 siswa dikualifikasikan baik kemampuan berpikir analitisnya, dan sisanya sebesar 14,29\% dengan jumlah 4 siswa dikualifikasikan cukup kemampuan berpikir analitisnya. Tidak ada siswa (0\%) yang diklasifikasikan kurang dan sangat kurang.

Tabel 2. Distribusi Frekuensi Kemampuan Berpikir Analitis Siswa Kelas Kontrol

\begin{tabular}{lllll}
\hline Klasifikasi & Nilai & Kualifikasi & Frekuensi & $\begin{array}{l}\text { Persentase } \\
(\%)\end{array}$ \\
\hline A & $86-100$ & Sangat Baik & 4 & 13,79 \\
B & $71-85$ & Baik & 14 & 48,28 \\
C & $56-70$ & Cukup & 11 & 37,93 \\
D & $41-55$ & Kurang & 0 & 0 \\
E & $\leq 40$ & Sangat Kurang & 0 & 0 \\
\hline Total & & & 29 & 100 \\
\hline
\end{tabular}


Data hasil dari distribusi frekuensi kemampuan berpikir analitis siswa kelas kontrol (XI IPS 2) menunjukkan bahwa sebesar 62,07\% memiliki kemampuan berpikir analitis yang baik sampai sangat baik, dapat dilihat sebesar $13,79 \%$ dengan jumlah sebanyak 4 siswa dikualifikasikan sangat baik kemampuan berpikir analitisnya, sedangkan sebesar 48,28\% dengan jumlah 14 siswa dikualifikasikan baik kemampuan berpikir analitisnya, dan sisanya sebesar 37,93\% dengan jumlah 11 siswa dikualifikasikan cukup kemampuan berpikir analitisnya. Tidak ada siswa (0\%) yang diklasifikasikan kurang dan sangat kurang.

Pada penelitian ini menggunakan uji hipotesis untuk membuktikan apakah sesuai dengan hipotesis yang telah dibuat. Setelah dilakukan uji prasyarat dengan hasil data telah terdistribusi normal dan homogen, kemudian dilakukan uji hipotesis. Uji hipotesis pada penelitian ini menggunakan uji-t (independent sampel $t$-test) dengan taraf signifikansi 0,05. Hasil perhitungan uji hipotesis menggunakan uji-t dapat dilihat pada Tabel 3 sebagai berikut.

Tabel 3. Hasil Perhitungan Uji-t

\begin{tabular}{lccc}
\hline Kelas & $\mathrm{N}$ & Mean & Signifikansi \\
\hline $\begin{array}{l}\text { Eksperimen (Discovery Learning } \\
\text { berbantuan LKS) }\end{array}$ & 28 & 82,00 & 0,003 \\
$\begin{array}{l}\text { Kontrol } \\
\text { (29 }\end{array}$ & 75,59 & 0,003 \\
\hline
\end{tabular}

Berdasarkan tabel hasil perhitungan uji-t bahwa kelas eksperimen yang telah diberikan perlakuan dengan model discovery learning berbantuan LKS menunjukkan hasil yang lebih unggul dibandingkan dengan kelas kontrol yang tidak diberikan model discovery learning dengan nilai signifikansi 0,003 atau $<0,05$. Maka dapat disimpulkan bahwa H0 ditolak dan H1 diterima, sehingga model pembelajaran discovery learning berbantuan lembar kegiatan siswa (LKS) berpengaruh terhadap kemampuan berpikir analitis siswa kelas XI SMAN 1 Gondanglegi.

Karakteristik model discovery learning yaitu pembelajaran yang berpusat pada siswa. Proses pembelajaran dalam model discovery siswa didorong untuk belajar sendiri melalui keterlibatan aktif dengan konsep-konsep yang ada, siswa juga dapat belajar berpikir analitis dengan mencoba memecahkan sendiri masalah yang mereka hadapi (Hosnan, 2014). Dalam discovery siswa tidak hanya diberikan teori saja, tetapi siswa dihadapkan dengan sejumlah fakta sehingga dapat menghasilkan sebuah penemuan. Karakteristik tersebut dapat meningkatkan kemampuan berpikir siswa melalui langkah-langkah dalam model discovery learning secara bertahap.

Penggunaan LKS dalam model discovery learning digunakan sebagai media yang dapat menstimulus siswa untuk aktif dalam pembelajaran. LKS dapat digunakan pentunjuk untuk melakukan kegiatan yang berkaitan dengan pembelajaran yang bertujuan untuk memudahkan siswa dalam memahami materi, sehingga siswa dapat termotivasi dalam proses pembelajaran. Model discovery learning berbantuan LKS ini berpengaruh terhadap kemampuan berpikir analitis siswa. Kemampuan berpikir analitis termasuk dalam kemampuan berpikir tingkat tinggi yang diperlukan ketika menghadapi perkembangan jaman. Siswa diharapkan mampu berpikir analitis untuk menyelesaikan masalah dari diri mereka sendiri, lingkungan sekitar, dan khususnya lingkungan sekolah. Siswa yang memiliki kemampuan berpikir analitis akan mudah memecahkan masalah yang mereka hadapi dengan hasil yang optimal (Assegaff dkk, 
2016). Proses dalam pembelajaran model discovery learning berbantuan LKS ini, didasarkan pada permasalahan di lingkungan siswa tentang pengaruh globalisasi terhadap budaya nasional. Selain itu, siswa dituntut untuk mencari dan mengumpulkan data secara mandiri di lapangan. Kemudian siswa secara berkelompok melakukan pengolahan data sehingga mendapatkan sebuah kesimpulan dari permasalahan tersebut. Melalui proses tersebut maka kemampuan berpikir analitis siswa akan terasah, karena mereka akan terlatih berpikir analitis untuk memahami informasi dan dapat menghubungkan antar komponen berdasarkan data yang didapatkan dari lapangan.

Kegiatan yang dilakukan siswa telah disesuaikan untuk dapat mencapai indikator kemampuan berpikir analitis. Indikator kemampuan berpikir analitis siswa antara lain: (1) mengidentifikasi masalah dan dapat mengaitkan dengan konsep yang ada ataupun data yang mendukung, (2) membedakan suatu hal berdasarkan fakta-fakta dari permasalahan yang ada, (3) memahami hubungan unsur-unsur dari suatu permasalahan yang menjadi sebuah kesimpulan.

Indikator yang pertama yaitu mengidentifikasi masalah dan dapat mengaitkan dengan konsep yang ada ataupun data yang mendukung. Discovery learning dapat mempengaruhi kemampuan berpikir analitis siswa karena dalam pembelajaran siswa dilibatkan secara aktif. Salah satu model pembelajaran yang dapat meningkatkan keaktifan siswa adalah model discovery learning. Menurut Bruner dalam Andriani dkk (2017) menganggap discovery atau belajar penemuan merupakan cara terbaik siswa aktif dalam pencarian pengetahuan. Proses pembelajaran pada discovery ini berpusat pada siswa sebagai pembelajaran dan guru hanya sebagai fasilitator dalam proses pembelajaran. Pembelajaran discovery ini melibatkan siswa secara penuh mulai dari kegiatan mengidentifikasi masalah, mengolah data hingga kegiatan menarik kesimpulan dari permasalahan globalisasi yang mempengaruhi kebudayaan di lingkungan siswa.

Kegiatan siswa dalam model discovery learning berbantuan LKS ini, siswa berdiskusi dengan kelompoknya tentang permasalahan yang telah dibagikan oleh guru. Menurut Ermi, (2015) kegiatan diskusi dapat menumbuhkan motivasi siswa untuk berpikir atau mengemukakan pendapatnya sendiri. Siswa dalam kelompoknya mengidentifikasi masalah tentang pengaruh interaksi global terhadap kebudayaan nasional terutama di lingkungan mereka saat ini. Setelah mengidentifikasi masalah, siswa dapat membuat rumusan masalah dari permasalahan yang ditemukan. Dalam proses tersebut siswa dapat aktif untuk menyampaikan gagasan mereka dalam pembuatan hipotesis. Pada tahap tersebut siswa dapat menggunakan data atau konsep yang mendukung untuk membuat hipotesis dari rumusan masalah yang telah dibuat. Kegiatan tersebut siswa dapat mencapai indikator yang pertama yaitu dapat mengaitkan dengan konsep yang ada ataupun data yang mendukung.

Indikator yang kedua yaitu membedakan suatu hal berdasarkan fakta-fakta dari permasalahan yang ada. Diskusi juga dilakukan untuk merencanakan tentang perencanaan studi lapangan yang akan di lakukan setiap kelompok sesuai topik yang telah didapatkan untuk mengumpulkan data yang dibutuhkan. Sebelumnya siswa menyusun instrumen wawancara yang digunakan untuk mencari data pada narasumber secara mandiri, dalam kegiatan studi lapangan tersebut siswa dapat berperan aktif untuk mendapatkan data yang mereka butuhkan sesuai dengan topik masing-masing kelompok. Hasil dari kegiatan tersebut dapat terlihat pada hasil kerja LKS siswa pada saat persentasi. Siswa dapat menuangkan gagasan dan 
menyampaikan hasil dari kerja kelompok mereka dengan permasalahan tentang kebudayaan. Pada saat persentasi terdapat interaksi tanggapan dengan kelompok lain dan mampu menjawab pertanyaan yang diajukan oleh siswa lain.

Model discovery learning berbantuan LKS ini menghadapkan siswa dengan permasalahan yang ada di lapangan secara langsung. Hal tersebut dapat mempengaruhi kemampuan berpikir analitis siswa. Kegiatan dalam model discovery learning menekankan pada kegiatan studi lapangan. Model discovery learning yang dipadukan dengan LKS ini akan mengintegrasikan kegiatan studi lapangan siswa secara berkelompok. Lembar kegiatan siswa berisikan petunjuk ataupun langkah-langkah yang digunakaan untuk menyelesaikan tugas yang mengacu pada kompetensi dasar yang harus dicapai Prastowo dalam Hidayah (2015). Dengan adanya LKS akan membantu siswa dalam proses studi lapangan sesuai petunjuk atau langkah-langkah yang terdapat dalam LKS. Kegiatan studi lapangan dapat membantu siswa mendapatkan gambaran secara nyata tentang permasalahan interaksi global yang mempengaruhi pola perilaku kebudayaan masyarakat Indonesia terutama di lingkungan siswa sendiri, sehingga siswa tidak hanya membayangkan tentang permasalahan yang harus diselesaikan. Ketrampilan siswa dalam penelitian juga akan terasah dalam kegiatan tersebut karena siswa melakukan kegiatan studi lapangan secara mandiri tanpa guru mendampinginya.

Kegiatan studi lapangan yang dilakukan oleh setiap kelompok berbeda-beda sesuai dengan topik yang telah mereka dapatkan. Terdapat dua topik dalam kegiatan tersebut. Dua kelompok mendapatkan topik pengaruh globalisasi dibidang sosial budaya yaitu pengaruh globalisasi terhadap tingkat konsumtif dan tiga kelompok lainya mendapatkan topik pengaruh globalisasi dibidang teknologi yaitu pengaruh gadget terhadap sikap individualis. Salah satu contoh hasil kerja dari kelompok yang mendapatkan topik pengaruh penggunaan gadget terhadap sikap individualis. Kelompok tersebut memilih narasumber yang dianggap sesuai dengan topik permasalahannya yaitu teman sebaya, karena remaja SMA salah satu generasi yang paling akrab dengan gadget. Setelah mereka melakukan wawancara dengan instrumen pertanyaan yang telah dibuat sebelumnya, siswa mendapatkan data tentang bagaimana gadget mempengaruhi sikap individualis seseorang. Mulai dari penyebab dan akibat yang ditimbulkan dari penggunaan gadget tersebut serta solusi yang mereka tawarkan untuk mengurangi pengaruh negatif seperti sikap individualis akibat penggunaan gadget.

Data yang telah mereka dapatkan dari lapangan kemudian diolah dan dianalisis lebih lanjut. Hasil analisis tersebut dituliskan dalam lembar hasil diskusi kelompok yang terdapat dalam LKS masing-masing kelompok dan dipersentasikan di depan kelas. Kegiatan tersebut dapat membantu siswa memperoleh data dan lebih mendalami permasalahan karena dari data yang telah didapatkan siswa akan menganalisis dan mengaitkan masalah yang dihadapi dengan data yang diperoleh sehingga menemukan jawaban atau solusi dari permasalahan yang ada. Melalui kegiatan tersebut siswa dapat mencapai indikator berpikir analitis yang kedua yaitu membedakan suatu hal berdasarkan fakta-fakta dari permasalahan yang ada. Hal tersebut ditunjukkan dengan perbedaan antara data yang kelompok peroleh dari narasumber dan hipotesis yang telah mereka buat sebelumnya, sehingga mereka berpikir untuk menemukan jawaban yang relevan dari permasalahan dan dapat memecahkannya.

Indikator yang ketiga adalah memahami hubungan unsur-unsur dari suatu permasalahan yang menjadi sebuah kesimpulan. Kegiatan penemuan dalam discovery learning menempatkan siswa untuk bekerja secara berkelompok untuk memecahkan permasalahan 
yang telah diberikan. Kegiatan yang mendukung dalam memecahkan masalah pada discovery learning yaitu pengumpulan data. Kegiatan pengumpulan data tersebut dapat membantu siswa memperoleh informasi yang lebih jelas tentang masalah kebudayaan yang ada di lingkungan mereka.

Data yang telah diperoleh dari lapangan dan diolah serta dianalisis, siswa melakukan kegiatan verifikasi dari hipotesis yang telah dibuat sebelumnya. Pada tahap verifikasi tersebut siswa dapat menghubungkan unsur-unsur dari jawaban yang didapatkan dari narasumber ataupun informasi yang telah mereka peroleh dengan hipotesis yang telah dibuat. Berdasarkan informasi yang telah mereka dapatkan itulah akan membuat siswa lebih memahami akar dari permasalahan pengaruh adanya globalisasi pada kebudayaan masyarakat Indonesia, Sehingga siswa dapat menarik kesimpulan dari hasil kerja kelompok dalam bentuk pernyataan maupun solusi. Melalui kegiatan tersebut siswa dapat mencapai indikator berpikir analitis yang ketiga yaitu memahami hubungan unsur-unsur dari suatu permasalahan yang menjadi sebuah kesimpulan. Melalui kegiatan tersebut siswa dapat memberikan gagasan atau hasil temuan dari proses pemikiran siswa. Siswa juga mampu menganalisis data yang telah mereka peroleh dari narasumber dan menghubungkan informasi maupun konsep yang berkaitan dengan permasalahan yang dihadapi sebelum membuat suatu kesimpulan.

Kelebihan dari model discovery learning yaitu pengetahuan yang diperoleh dari model ini sangat pribadi dan efektif karena menguatkan pengertian, ingatan (memori jangka panjang) serta transfer mengenai materi pembelajaran yang dipelajari (Nurrohmi, 2017). Kemampuan tersebut membuat siswa menjadi lebih mudah untuk menguasai materi pembelajaran. Salah satu yang menjadi tolak ukur dari pembelajaran discovery learning adalah internalisasi peristiwa menjadi sistem penyimpanan yang sesuai dengan lingkungan (Bruner, 1966). Hal tersebut menyebabkan pelaksanaan dari model ini ada yang dilakukan di luar kelas atau dilingkungan secara langsung. Siswa akan langsung melakukan kegiatan pengamatan di lingkungan untuk memperoleh data di lapangan. Kegiatan pengamatan secara langsung dilapangan diharapkan siswa dapat mengkombinasikan pengetahuan siswa yang telah didapatkan dikelas dengan kondisi sebenarnya di lapangan. Harapan dari kegiatan tersebut pembelajaran akan lebih bermakna dan dapat tersimpat dalam memori siswa. Pengalaman siswa tersimpan dalam memori terbukti saat siswa dapat menjawab soal tes yang diberikan. Pengalaman dilapangan secara langsung akan mudah dipahami siswa dan tersimpan dalam ingatan, sehingga siswa dengan mudah menjawab soal dengan memori yang telah tersimpan tersebut.

Lembar kegiatan siswa (LKS) memiliki peran yang cukup besar untuk membantu pembelajaran discovery. Pada discovery learning, LKS berperan sebagai media yang dapat mempermudah tercapainya tujuan pembelajaran. Karena LKS merupakan panduan belajar yang dapat memberikan stimulus siswa untuk mengasah kemampuan analitisnya melalui soalsoal diskusi ataupun soal latian yang ada dalam LKS tersebut (Nurisah dkk, 2019). Pendapat tersebut sejalan dengan hasil penelitian yang dilakukan oleh( Aptinata, 2017), kelas yang diberikan model discovery learning berbantuan LKS berjalan dengan optimal dan kondusif. Discovery learning berbantuan LKS adalah pembelajaran yang mengajak siswa untuk melakukan penemuan yang didalamnya berisi tugas-tugas yang telah terstruktur dan siswa harus mengerjakannya sehingga guru membimbing siswa untuk melakukan kegiatan pembelajaran yang bertujuan agar siswa lebih memahami materi yang diajarkan. 
Proses pengerjaan LKS guru membantu siswa dan memberikan contoh untuk pengisian LKS, karena siswa tidak langsung memahami langkah dalam kegiatan LKS. Setelah siswa memahami, mereka dapat mengisi LKS tersebut sesuai dengan kreatifitas siswa dengan berbagai pandangan yang mereka gunakan untuk menganalisis permasalahan yang dihadapi. Kondisi tersebut dapat dinamakan dengan discovery learning environment. Lingkungan dapat digunakan siswa untuk melakukan eksplorasi dan mendapatkan penumuan-penemuan baru yang sebelumnya belum siswa ketahui (Slameto, 2010). Kondisi tersebut dapat mengembangkan kemampuan berpikir analitis siswa dan dapat meningkatkan pemahaman akan materi yang mereka pelajari.

Selain melatih kemampuan berpikir analitis siswa, model discovery learning berbantuan LKS ini juga membantu siswa untuk dapat memecahkan masalah dengan kritis, sistematis, dan logis. Hal tersebut sesuai dengan pendapat (Hanafiah dan Suhana, 2009) yang mengatakan bahwa, model discovery learning adalah rangkaian dari suatu kegiatan pembelajaran yang melibatkan siswa secara penuh untuk mencari dan menyelidiki permasalahan dengan kritis, sistematis, dan logis, sehingga siswa dapat menemukan pengetahuan, ketrampilan dan sikap dari wujud adanya perubahan perilaku. Siswa akan berpikir kritis dan logis untuk mengidentifikasi masalah dan membuat hipotesis. Kemudian siswa akan berpikir sistematis untuk dapat memecahkan permasalahan sesuai dengan tahapan dalam LKS.

Perpaduan antara model discovery learning dengan LKS memberikan pengaruh yang baik dalam pembelajaran. Implementasi model discovery learning berbantuan LKS memberikan dampak positif terhadap kompetensi belajar siswa pada ranah kognitif. Perpaduan model discovery learning dengan LKS sebagai bahan diskusi siswa memberikan dampak yang positif bagi guru, karena sebagian waktu guru dapat dicurahkan untuk membimbing belajar siswa. Sedangkan, dampak positif pada siswa dapat mempengaruhi pola interaksi siswa dengan memberikannya peluang yang sama pada siswa untuk mendapatkan pengalaman secara langsung dalam memperoleh informasi tentang materi yang dipelajari (Eriza dkk, 2015). Hasil penelitian yang dilakukan Lubis dkk (2016), menyatakan bahwa penerapan model discovery learning berbantuan LKS telah membawa siswa ke dunia nyata sehingga lebih mudah memahami materi. Materi pengaruh interaksi global terhadap kebudayaan nasional dengan menggunakan model discovery learning berbantuan LKS memberikan siswa pengalaman belajar yang bermakna dan dapat lebih dipahami oleh siswa karena, siswa terjun langsung dalam lingkungan dengan permasalahan tersebut. Selain itu, siswa dapat melakukan diskusi dengan lebih terarah dan terstruktur menggunakan LKS.

Pengaruh model discovery learning berbantuan LKS terhadap kemampuan berpikir analitis siswa pada kelas eksperimen memberikan hasil yang cukup signifikan. Pengaruh tersebut terlihat pada tahapan-tahapan kegiatan dalam model discovery learning berbantuan LKS sejalan dengan indikator kemampuan berpikir analitis. Tahapan-tahapan kegiatan tersebut antara lain: (1) stimulasi, (2) identifikasi masalah, (3) pengumpulan data, (4) pengolahan data, (5) verifikasi, dan (6) penarikan kesimpulan (Syah, 2004).

Tahapan pertama yaitu stimulasi. Tahap ini siswa disajikan video tentang pengaruh globalisasi terhadap kebudayaan nasional. Penayangan video tersebut bertujuan untuk menarik perhatian siswa dan memberikan gambaran kepada siswa tentang materi yang akan dipelajari pada pembelajaran tersebut. Setelah siswa mengamati video tersebut, siswa mengemukakan pokok bahasan yang ada dalam video tersebut. 
Tahapan yang kedua identifikasi masalah. pada tahap ini siswa sudah dibagi menjadi 5 kelompok. Pada tahap ini siswa diberikan kesempatan untuk mengidentifikasi masalah tentang pengaruh globalisasi terhadap kebudayaan nasional. Pada tahap kedua ini kemampuan analitis siswa mulai diasah, dengan mengidentifikasi permasalahan yang dekat dengan lingkungan mereka sendiri. Dengan begitu siswa akan mudah menganalisis permasalahan karena memiliki gambaran yang nyata. Selain itu pada tahap ini siswa juga membuat rumusan masalah dan hipotesis dari permasalahan yang telah diidentifikasi.

Tahap ketiga yaitu pengumpulan data. Sebelum melakukan pengumpulan data di lapangan. Setiap kelompok membuat perancaan pengumpulan data untuk memudahkan mereka mendapatkan informasi yang dibutuhkan sesuai topik permasalahan. Kegiatan perencanaan pengumpulan data, setiap kelompok menyusun atau merancang data apa yang akan dibutuhkan, sumber dari data tersebut, instrumen yang digunakan dalam pengumpulan data dan lain-lain. Kegiatan pengumpulan data yang dilakukan, siswa melakukan wawancara kepada narasumber yang relevan dengan topik permasalahan, mulai dari teman sebaya sampai tetangga siswa sendiri. Wawancara menggunakan instrumen pengumpulan data yang telah dibuat sebelumnya. Kegiatan tersebut melatih siswa untuk belajar berkomunikasi dan melatih kegiatan penyelidikan di lapangan secara sistematis dan logis.

Tahap keempat yaitu pengolahan data. Pada tahap pengolahan data ini data yang diperoleh sebelumnya diolah dan dianalisis lebih lanjut. Siswa melakukan pengolahan data berdasarkan informasi atau data yang sudah diperoleh dari penyelidikan untuk mendukung kebenaran hipotesis. Siswa akan mengelompokkan data yang telah mereka peroleh. Kemudian setelah dikelompokkan data tersebut dianalisis. Melalui kegiatan diskusi kelompok tersebut membuat siswa terlatih untuk mengemukakan pendapat atau menyampaikan gagasangagasan yang menurut mereka tepat dari analisis data tersebut. Melalui berbagai pertimbangan seperti mengevaluasi data atau informasi yang telah dikumpulkan, menentukan tingkat kepercayaan dari sumber data atau informasi, dan mempertimbangkan berbagai pendapat yang telah disampaikan dalam diskusi kelompok berdasarkan kelebihan secara logis dari argumen.

Tahap kelima yaitu verifikasi. Tahap verifikasi ini merupakan tahap siswa melakukan pembuktian dari hipotesis yang telah dibuat. Tahap inilah siswa dilatih untuk menganalisis data yang telah didapatkan di lapangan dengan hipotesis siswa. Hasilnya terdapat kelompok yang sesuai dengan hipotesis yang telah dibuat, tetapi ada juga kelompok yang tidak sesuai antara data yang didapatkan dengan hipotesis. Perbedaan itulah yang dapat melatih siswa untuk memahami hubungan berbagai unsur dari data yang mereka dapatkan di lapangan dengan hipotesis yang dibuat. Sehingga memunculkan berberapa argumen tiap kelompok yang berkaitan dengan kegiatan lapangan mereka.

Tahap yang terakhir yaitu generalisasi atau penarikan kesimpulan. Tahap ini adalah tahap penarikan kesimpulan dari proses kegiatan sebelumnya. Kegiatan pada tahap ini siswa membuat kesimpulan berupa pernyataan akhir atau solusi dari permasalahan pada tiap kelompok. Kegiatan penarikan kesimpulan ini membantu siswa untuk mengambil sebuah keputusan dari penyelidikan yang telah dilakukan. Berdasarkan dari perbedaan dan persamaan informasi atau data yang didapatkan tersebut membantu siswa dalam kegiatan lebih lanjut. Proses dari pembelajaran tersebut siswa tidak hanya mendapatkan pengalaman 
baru, tetapi juga mendapatkan pengetahuan baru yang sebelumnya mungkin belum mereka ketahui.

\section{Simpulan}

Simpulan dari penelitian ini berdasarkan rumusan masalah dan hasil penelitian diperoleh yaitu model pembelajaran discovery learning berbantuan lembar kegiatan siswa (LKS) berpengaruh terhadap kemampuan berpikir analitis siswa. Dengan kata lain, kemampuan berpikir analitis siswa pada kelas eksperimen yang diberikan perlakuan model discovery learning berbantuan LKS memperoleh nilai rata-rata lebih tinggi dibandingkan dengan kelas kontrol yang diberikan pembelajaran konvensional.

Berdasarkan dari kesimpulan yang telah dipaparkan, saran yang dapat diajukan sebagai berikut. Pertama, bagi sekolah Model discovery learning berbantuan LKS dapat menjadi saran sekolah untuk menghimbau guru-guru di sekolah untuk menerapkan model discovery learning berbantuan LKS untuk meningkatkan kemampuan berpikir analitis siswa. Kedua, Saran yang diajukan pada guru untuk menggunakan model discovery learning pada pembelajaran geografi, terutama pada materi geografi yang kontekstual. Ketiga, Saran bagi peneliti selanjutnya dapat melakukan pengujian lebih lanjut tentang model discovery learning dengan variabel terikat lain dan dapat menambahkan variabel moderator.

\section{Daftar Rujukan}

Andriani, Dini, dkk. (2017). Pembelajaran Discovery Learning Untuk Meningkatkan Kemampuan Metakognisi dan Penguasaan Konsep Siswa. (Online) (http://jurnal.fkip.unila.ac.id/index.php/JPK/article/view/13308) diakses pada 9 Oktober 2019.

Angryawan, Veri. (2016). Pengaruh Model Pembelajaran Discovery Based Learning (DBL) Materi Geografi Sub Bab Ketahanan Pangan Nasional Terhadap Kemampuan Berpikir Kritis Siswa Kelas XI MAN Kota Batu. Skripsi tidak diterbitkan. Malang: Universitas Negeri Malang.

Aptinata, I Made R.W. (2017). Pengaruh Model Discovery Learning Berbantuan LKS Terhadap Hasil Belajar IPS Siswa Kelas V. (Online), (https://ejournal.undiksha.ac.id) diakses pada 16 juni 2020.

Assegaff \& Santoni. (2016). Upaya Meningkatkan Kemampuan Berpikir Analitis Melalui Model Problem Based Learning (PBL). (Online), (https://ejournal.upi.edu), diakses pada 29 Oktober 2019.

Astriani, Dyah., dkk. (2017). Profil Ketrampilan Berpikir Analitis Mahasiswa Calon Guru IPA dalam Perkuliahan Biologi Umum. (Online), (https://journal.unesa.ac.id/index.php/jppipa/article/view/3093) diakses pada 18 Oktober 2019.

Bruner, J. S. (1966). Toward a Theory of Instruction. Cambridge. MA: Harvard University Press.

Depdiknas. (2005). Pedoman Penyusunan LKS SMA. Jakarta: Depdiknas.

Eriza, Deni Septia, dkk. (2015). Pengaruh Model Discovery Learning Berbantuan Lembar Kegiatan Siswa (LKS) Terdapat Pencapain Kompetensi Belajar Biologi Siswa Kelas VIII di SMP Negeri 6 Sungai Penuh. (Online), (http://ejournal.unp.ac.id) diakses pada 14 Juni 2020.

Ermi, Netti. Penggunaan Metode Diskusi untuk Meningkatkan Hasil Belajar Materi Perubahan Sosial pada Siswa Kelas XII SMA Negeri 4 Pekanbaru. (Online), (https://sorot.ejournal.unri.ac.id/index.php/IS/article/view/3212/0) diakses 14 Mei 2020.

Hanafiah dan Suhana. (2009). Konsep Strategi Pembelajaran. Bandung: Refika Aditama.

Hosnan. (2014). Pendekatan Saintifik dan Konstektual dan Konstektual dalam Pembelajaran Abad 21 Kunci Sukses Implementasi Kurikulum 2013. Bogor: Ghalia Indonesia.

Imanda, Teguh Dwi. (2018). Pengaruh Model Pembelajaran Discovery Learning Terhadap Kemampuan Berpikir Kritis Siswa Pada Mata Pelajaran Geografi Kelas X SMAN 10 Malang, (Online) (http://karyailmiah.um.ac.id/index.php/Geografi/article/view/73625) diakses pada 30 Oktober 2019. 
Jurnal Integrasi dan Harmoni Inovatif Ilmu-Ilmu Sosial (JIHI3S), 1(3), 2021, 350-360

Lubis, Mutiara, dkk. (2016). Peningkatan Aktivitas dan Kompetensi Belajar IPA Siswa dengan Menggunakan Model Pembelajaran Discovery Learning Berbantuan LKS di Kelas VII MTs. Muhammadiyah 22 Padangsidipuan. (Online), (http://jurnal.um-tapsel.ac.id) diakses pada 14 Juni 2020.

Nurisah, Reti Prabaraita, dkk. (2019). Penerapan Model Pembelajaran Discovery Learning Berbantuan Lembar Kerja Siswa (LKS) Untuk Meningkatkan Kemampuan Analisis dan Prestasi Belajar Siswa pada materi Konsep Mol Kelas X SMA Negeri 1 Boyolali Tahun Ajaran 2017/2018. (Online), (https://jurnal.uns.ac.id) diakses pada 16 Juni 2020.

Nurrohmi, Yusnia. (2017). Pengaruh Model Pembelajaran Discovery Learning Terhadap Kemampuan Berpikir Kritis Mahasiswa. (Online), (https://media.neliti.com/media/publications/211656-pengaruh-modelpembelajaran-discovery-le.pdf) diakses 07 Agustus 2020.

Prastowo, Andi. (2014). Panduan Membuat Bahan Ajar Inovatif. Yogyakarta: DIVA Press.

Riana, Erdina Elfi. (2016). Pengaruh Model Pembelajaran Penemuan (Discovery Learning) Terhadap Ketrampilan geografi Peserta Didik di SMAN 1 Talun. Skripsi tidak diterbitkan. Malang: Universitas Negeri Malang.

Slameto. (2010). Belajar Dan Faktor-Faktor Yang Mempengaruhi. Jakarta: PT Rineka Cipta.

Syah, Muhibbin. (2004). Psikologi Pendidikan dengan Pendekatan Baru. Bandung: PT. Remaja Karya. 